\title{
Prevalence and risk factors for modified prescriptions in an Irish community pharmacy
}

\author{
S Obasi ${ }^{*}$, A Tinsley $^{2}$, F Doyle $^{1}$ \\ From International Conference for Healthcare and Medical Students (ICHAMS) 2013 \\ Dublin, Ireland. 11-12 October 2013
}

\section{Background}

Little research exists of rates of prescribing errors and prescription modifications, or risk factors for same, in Ireland.

\section{Methods}

A cross-sectional study was performed to examine prescriptions dispensed in a community pharmacy over a period of 5 weeks from November 19 to December 212012.

\section{Results}

In total, 866 prescriptions were examined. The overall prevalence of prescription modifications was $17.9 \%$ (155/866), with a mean of 31 modifications per week. Prescription only medicines (POM) comprised 147 (94.8\%) of the modifications, $128(87.1 \%)$ of which concerned a prescription error requiring a simple clerical clarification before dispensing could occur, with the remaining 19 (12.9\%; average of 3.8 per week) potentially having clinical consequences if left unaltered. Half (51\%) of all POM modifications occurred through consultation with the patient or their representative. The following factors were associated with increased risk of POM modifications: being a female patient $(\mathrm{OR}=1.605,95 \%$ CI 1.104-2.333, $\mathrm{p}=0.013)$ and being prescribed drugs in the following therapeutic areas: musculo-skeletal $(\mathrm{OR}=1.906,95 \%$ CI 1.023-3.551, $\mathrm{p}=$ $0.042)$ and genito urinary system and sex hormones ( $\mathrm{OR}=$ 3.691, 95\% CI 2.255-6.042, $\mathrm{p}<0.001$ ). Multivariate analysis showed these were significant independent determinants of POM modifications, remaining so after adjustment.

\section{Conclusions}

The majority of prescribing errors modified involved non-serious clerical errors. However an average of

${ }^{1}$ Division of Population Sciences (Psychology), Royal College of Surgeons Ireland, 123 St. Stephen's Green, Dublin 2. Ireland

Full list of author information is available at the end of the article
3.8 POM prescriptions with potential clinical consequences were modified weekly.

\section{Authors' details}

${ }^{1}$ Division of Population Sciences (Psychology), Royal College of Surgeons Ireland, 123 St. Stephen's Green, Dublin 2. Ireland. 'McCabes Pharmacy, Dublin, Ireland.

Published: 14 January 2015

doi:10.1186/1753-6561-9-S1-A48

Cite this article as: Obasi et al:: Prevalence and risk factors for modified prescriptions in an Irish community pharmacy. BMC Proceedings 2015 9(Suppl 1):A48.
Submit your next manuscript to BioMed Central and take full advantage of:

- Convenient online submission

- Thorough peer review

- No space constraints or color figure charges

- Immediate publication on acceptance

- Inclusion in PubMed, CAS, Scopus and Google Scholar

- Research which is freely available for redistribution

Submit your manuscript at www.biomedcentral.com/submit

\section{() Biomed Central}

C Biomed Central

(C) 2015 Obasi et al; licensee BioMed Central Ltd. This is an Open Access article distributed under the terms of the Creative Commons Attribution License (http://creativecommons.org/licenses/by/4.0), which permits unrestricted use, distribution, and reproduction in any medium, provided the original work is properly cited. The Creative Commons Public Domain Dedication waiver (http:// creativecommons.org/publicdomain/zero/1.0/) applies to the data made available in this article, unless otherwise stated. 